Supporting Information

\title{
A Single Amino Acid Switch Between a Flavin-Dependent Dehalogenase and Nitroreductase
}

\author{
Arnab Mukherjee and Steven E. Rokita* \\ Department of Chemistry, Johns Hopkins University, Baltimore, MD, USA \\ Email: rokita@jhu.edu
}

\section{CONTENTS}

1) MATERIAL AND METHODS

2) FIGURE S1. Active site binding of $\mathrm{I}_{2}-\mathrm{Tyr}$ and $\mathrm{O}_{2} \mathrm{~N}-\mathrm{Tyr}$ to wt hhIYD and its T173A mutant. S3

3) FIGURE S2. Catalytic deiodination of $\mathrm{I}_{2}-\mathrm{TYR}$ by wt hhIYD and its T173A mutant. $\quad$ S4

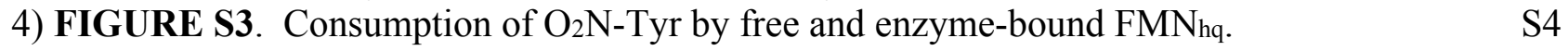

5) FIGURE S4. Mass spectroscopy of the dansylation reaction product. $\quad$ S5

6) FIGURE S5. Stoichiometry of $\mathrm{O}_{2} \mathrm{~N}-\mathrm{Tyr}$ reduction by FMN $\mathrm{N}_{\mathrm{hq}}$ bound to T173A hhIYD. $\quad$ S5

7) FIGURE S6. HPLC analysis of reaction between sodium bisulfite and $\mathrm{O}_{2} \mathrm{~N}-\mathrm{Tyr}$ and phenylhydroxylamine.

8) FIGURE S7. Multiple turnover of T173A hhIYD during reduction of $\mathrm{O}_{2} \mathrm{~N}-\mathrm{Tyr}$. $\quad$ S6

9) REFERENCES

\section{MATERIALS AND METHODS}

General materials. L-3,5-diiodotyrosine ( $\left.\mathrm{I}_{2}-\mathrm{Ty}\right)$, L-3-nitrotyrosine $\left(\mathrm{O}_{2} \mathrm{~N}-\mathrm{Tyr}\right), \mathrm{m}$-cresol, phenylhydroxylamine (PhNHOH), sodium bisulfite, and flavin mononucleotide (FMN) were obtained from Sigma. Dansyl chloride was purchased from Acros Organics. L-3-Aminotyrosine $\left(\mathrm{H}_{2} \mathrm{~N}-\mathrm{Tyr}\right)$ and L-fluorotyrosine (F-Tyr) were purchased from Chem Impex International and Astatech, Inc, respectively. Deep Vent high-fidelity DNA polymerase was obtained from New England Biolabs. Oligodeoxynucleotides were purchased from IDT (Integrated DNA Technology). Rosetta 2 and one shot TOP10 competent cells were obtained from EMD Millipore and Invitrogen, respectively.

General instrumentation. All UV-Vis absorbance data were measured by an Agilent 8453 UVVis spectrophotometer and fluorescence measurements used a Horiba Fluoromax 4c spectrofluorometer. HPLC separation and detection by UV-Vis absorbance were performed with an Agilent Technology 1100 series system and an Agilent microsorb-MV C-18 reverse-phase column $(250 \times 4.6$ $\mathrm{mm})$. Mass spectroscopy data were collected with a Waters Acquity UPLC-Xevo-G2-aTof-MS equipped with a $2.1 \times 50 \mathrm{~mm}$ BEH-C18 column $(1.7 \mu \mathrm{m}, 300 \AA$ pore size $)$.

Mutagenesis, expression and protein purification. The wt hhIYD gene within a pSMT3 plasmid for generating a His-tagged SUMO-IYD fusion protein ${ }^{1}$ was mutated to express the T173A enzyme by PCR with primers 5'-GCA CTT ACA CAT GCG CCC AGC CCA ATG 3' and 5'-CAT TGG GCT GGG CGC ATG TGT AAG TGC 3'. The resulting DNA was used to transform one shot TOP10 competent cells. The desired plasmid was isolated from this source and confirmed by DNA sequencing. The parent plasmid and its derivative containing the T173A mutant were used alternatively to transform $E$. coli Rosetta 2 competent cells for generating the wildtype (wt) and mutant enzymes as fusions with SUMO. Cells were then grown in LB media in the presence of chloramphenicol $(34 \mu \mathrm{g} / \mathrm{mL})$ and kanamycin $(50 \mu \mathrm{g} / \mathrm{mL})$ at $37^{\circ} \mathrm{C}$ for $2.5 \mathrm{hr}(\mathrm{OD} 600 \sim 0.7)$, induced by addition of IPTG $(30 \mu \mathrm{M})$ and further incubated overnight at $16^{\circ} \mathrm{C}$. The resulting cells were centrifuged at $5000 \mathrm{xG}$ at $4^{\circ} \mathrm{C}$, rinsed with lysis buffer $(50 \mathrm{mM}$ sodium phosphate, $\mathrm{pH} 8,100 \mathrm{mM}$ $\mathrm{NaCl}, 10 \%$ glycerol, $0.1 \mathrm{mM}$ DTT), flash frozen and finally stored at $-80^{\circ} \mathrm{C}$ until needed. For protein isolation, cells were thawed, resuspended in lysis buffer and lysed by passage through an Avestin 
EmulsiFlex C3 at 15,000 psi. FMN $(150 \mu \mathrm{M})$ was added to the cell lysate and the mixture was incubated for $10 \mathrm{~min}$ on ice before centrifugation at $40,000 \mathrm{xG}$ for $2 \mathrm{hr}$ at $4^{\circ} \mathrm{C}$ to remove cell debris. The supernatant was loaded onto a HisPur $\mathrm{Ni}^{2+}$-NTA column pre-equilibrated with lysis buffer and the column was washed successively with lysis buffer containing 20,60, $100 \mathrm{mM}$ imidazole to remove proteins lacking a His-tag. The SUMO-His-tag-IYD fusion was eluted with $300 \mathrm{mM}$ imidazole (in lysis buffer) and treated with Ulp1 $(1: 200 \mathrm{w} / \mathrm{w})$ overnight at $4{ }^{\circ} \mathrm{C}$ to lysis the SUMO-His-tag from IYD. The resulting mixture was concentrated to $1 \mathrm{~mL}$ with an Amicon Ultra-15 centrifugal filter and separated by size-exclusion chromatography (Sephacryl S-200, GE Healthcare) using a buffer of $50 \mathrm{mM}$ sodium phosphate $\mathrm{pH} 7.4,500 \mathrm{mM} \mathrm{NaCl}, 10 \%$ glycerol and $1 \mathrm{mM}$ DTT. Fractions containing IYD were initially detected by their yellow color and their purity was determined by SDS-PAGE gel. Samples of greater than $98 \%$ purity (ImageQuant software) were pooled, concentrated to $\sim 400 \mu \mathrm{M}$ and stored at $80^{\circ} \mathrm{C}$. Protein concentration was determined by A280 after subtracting the contribution from FMN $\left(\mathrm{A}_{280} / \mathrm{A}_{450}=1.57\right)^{1,2}$

Substrate-dependent oxidation of IYD-bound and free $\boldsymbol{F M N}_{\boldsymbol{h q}}$. Solutions of $100 \mathrm{mM} \mathrm{MES} \mathrm{pH}$ $6,500 \mathrm{mM} \mathrm{NaCl}, 10 \%$ glycerol and, when necessary for quantitation, an internal standard of $m$-cresol $(50 \mu \mathrm{M})$ were flushed for 30 min with a continuous flow of argon to remove all dissolved molecular oxygen. Equal concentrations $(18 \mu \mathrm{M})$ of wt hhIYD, its T173A mutant or free FMN were then added alternatively with continuous flushing by argon for another 2 min. Additional flushing of the head spaced was extended for another 30 min before minimal dithionite was added to fully reduce the FMN as monitored by loss of the A450 signal. To confirm that no excess dithionite was present in these mixtures, between 10 and $20 \mu \mathrm{L}$ of air saturated buffer was introduced into the mixture. This led to oxidization of $\sim 2-3 \mu \mathrm{M}$ of the $\mathrm{FMN}_{\mathrm{hq}}$ to form $\mathrm{FMN}_{\mathrm{ox}}$. The persistence of the resulting $\mathrm{A}_{450}$ from $\mathrm{FMN}_{\mathrm{ox}}$ was confirmed over $10 \mathrm{~min}$. Reaction was then initiated by addition of $8 \mu \mathrm{M} \mathrm{O}_{2} \mathrm{~N}-\mathrm{Tyr}$ or 10 $\mu \mathrm{M} \mathrm{I}_{2}$-Tyr in $100 \mathrm{mM}$ MES pH 6 . Spectral changes were monitored every $5 \mathrm{~s}$ for the first $10 \mathrm{~min}$ and every $30 \mathrm{~s}$ for the next $50 \mathrm{~min}$. One electron oxidation produced the characteristic absorbance at 585 $\mathrm{nm}$ for the neutral FMN $\mathrm{sq}_{\mathrm{sq}}\left(4900 \mathrm{M}^{-1} \mathrm{~cm}^{-1}\right)^{3}$ and two electron oxidation produced an equally characteristic absorbance at $450 \mathrm{~nm}$ for FMN $_{\text {ox }}\left(12,500 \mathrm{M}^{-1} \mathrm{~cm}^{-1}\right) .{ }^{4}$

Reduction of wt hhIYD and its T173A mutant by xanthine and xanthine oxidase. Individual samples containing $100 \mathrm{mM}$ MES pH 6, $500 \mathrm{mM} \mathrm{NaCl}, 10 \%$ glycerol, $1 \mathrm{mM}$ xanthine and $2 \mu \mathrm{M}$ methyl viologen in the presence or absence of $500 \mu \mathrm{M}$ F-Tyr as indicated were purged with argon in sealable cuvettes for 30 min prior to addition of $16 \mu \mathrm{M}$ IYD. Purging was continued in the head space of the cuvette for another $30 \mathrm{~min}$ to remove all molecular oxygen. Reduction was initiated by addition of $100 \mu \mathrm{g} / \mathrm{mL}$ xanthine oxidase. Spectral changes were monitored every $2 \mathrm{~min}$ for $15 \mathrm{hr}$.

Danyslation of products formed by the T173A mutant and their product standards.

Conditions for danyslation derive from a published procedure.5, ${ }^{6}$ A standard enzymatic reaction described above containing $18 \mu \mathrm{M} \mathrm{T173A}$ mutant and $8 \mu \mathrm{M}$ substrate was incubated under ambient conditions for $50 \mathrm{~min}$. An aliquot $(500 \mu \mathrm{L})$ of the resulting solution was combined with $\mathrm{Li}_{2} \mathrm{CO}_{3} \mathrm{pH}$ $10.5(170 \mu \mathrm{L})$ to raise the $\mathrm{pH}$ from 6.0 to 9.5 . Derivatization was initiated by addition of dansyl chloride $(500 \mu \mathrm{M})$ in acetonitrile $(3 \mathrm{mM}, 167 \mu \mathrm{L})$ and a second volume of acetonitrile $(167 \mu \mathrm{L})$ was added to raise its final concentration to $33 \%$. The mixture was incubated under ambient conditions in the dark for $1 \mathrm{hr}$ before the acetonitrile was removed under reduced pressure. The remaining material was analyzed by reverse-phase HPLC. To generate the chromatographic standards, commercial $\mathrm{O}_{2} \mathrm{~N}-$ Tyr and $\mathrm{H}_{2} \mathrm{~N}-\mathrm{TYR}(8 \mu \mathrm{M})$ were treated under equivalent condition by addition of the same enzymatic reaction buffer and subsequent treatment with $\mathrm{Li}_{2} \mathrm{CO}_{3}$, dansyl chloride and acetonitrile. Again, the acetonitrile was removed under reduced pressure and the remaining material was analyzed by HPLC (Figure 4). 

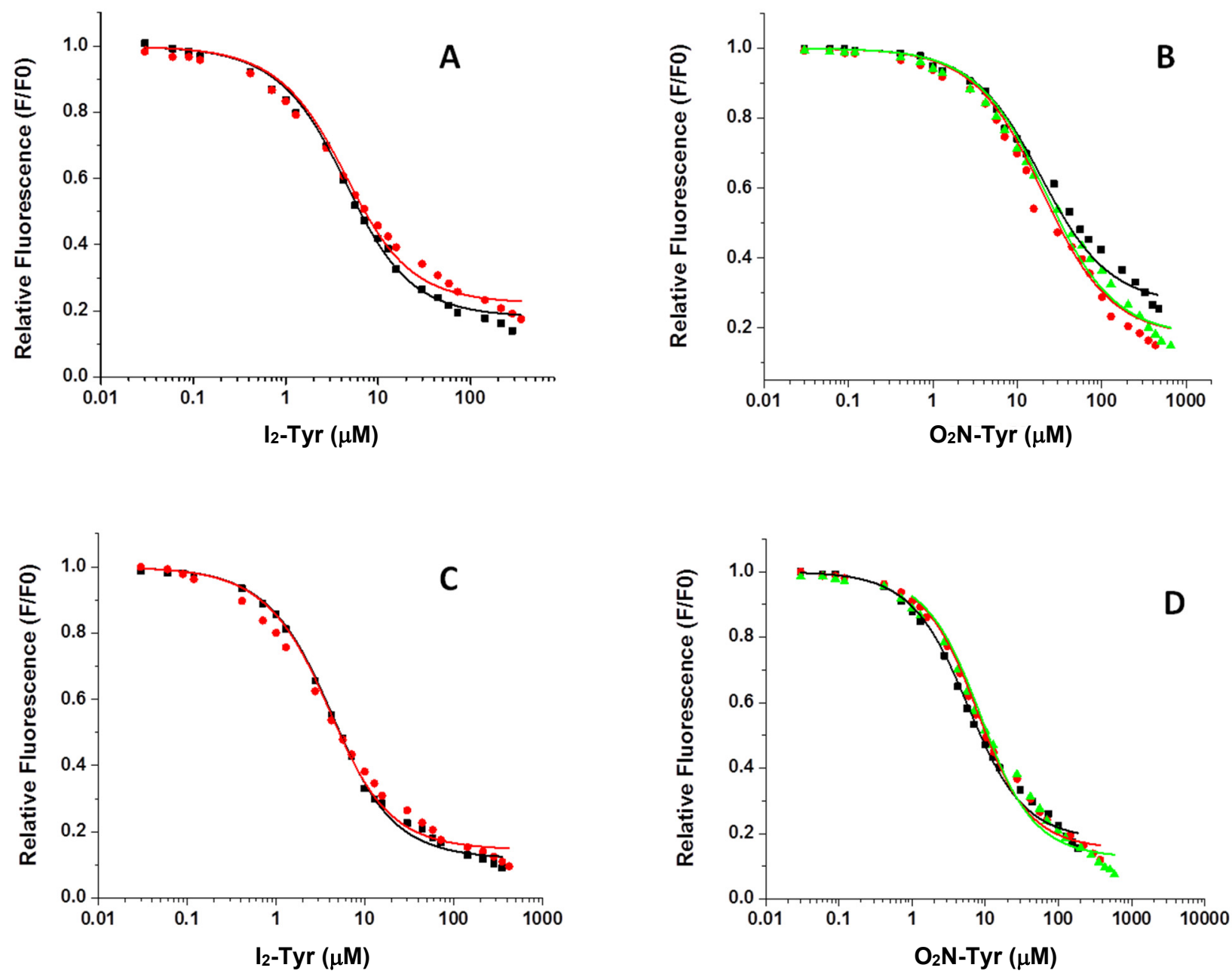

Figure S1. Active site binding of $\mathrm{I}_{2}$-Tyr and $\mathrm{O}_{2} \mathrm{~N}-\mathrm{Tyr}$ to wt hhIYD and its T173A mutant. Binding affinity of (A) $\mathrm{I}_{2}$-Tyr and (B) $\mathrm{O}_{2} \mathrm{~N}$-Tyr to wt hhIYD and (C) $\mathrm{I}_{2}$-Tyr and (D) $\mathrm{O}_{2} \mathrm{~N}$-Tyr to the T173A mutant were determined by the ability of bound ligand to quench the FMN fluorescence of the enzyme. Protein concentrations of 3 and $5 \mu \mathrm{M}$ were used for studies of $\mathrm{I}_{2}$-Tyr and $\mathrm{O}_{2} \mathrm{~N}-\mathrm{Ty}$, respectively. The higher concentration of protein was required for experiments involving $\mathrm{O}_{2} \mathrm{~N}-\mathrm{Tyr}$ to reduce the scatter of the data. All assays additionally contained $100 \mathrm{mM} \mathrm{MES} \mathrm{pH} \mathrm{6,} 500 \mathrm{mM} \mathrm{NaCl}$, and $10 \%$ glycerol. Fluorescence measurement $\left(\lambda_{\mathrm{ex}} 450 \mathrm{~nm}, \lambda_{\mathrm{em}} 520 \mathrm{~nm}\right)$ and data analysis followed published procedures. ${ }^{1,7}$ Assay solutions were incubated at $25^{\circ} \mathrm{C}$ for 30 min before initial addition of the ligands. Normalized fluorescence emission (final signal $(\mathrm{F}) /$ initial signal $\left(\mathrm{F}_{0}\right)$ ) was plotted against concentration of substrate $\left(\mathrm{S}_{0}\right)$ and dissociation constants were determined from equation $1 .{ }^{8}$ Each independent trial is represented by a different color. The average $K_{d}$ values are reported in Table 1.

$$
\mathrm{F}=\mathrm{F}_{0}+\Delta \mathrm{F}\left(\frac{\left(\mathrm{K}_{\mathrm{d}}+\mathrm{E}_{0}+\mathrm{S}_{0}\right)-\sqrt{\left(\mathrm{K}_{\mathrm{d}}+\mathrm{E}_{0}+\mathrm{S}_{0}\right)^{2}-4 \mathrm{E}_{0} \mathrm{~S}_{0}}}{2 \mathrm{E}_{0}}\right)
$$



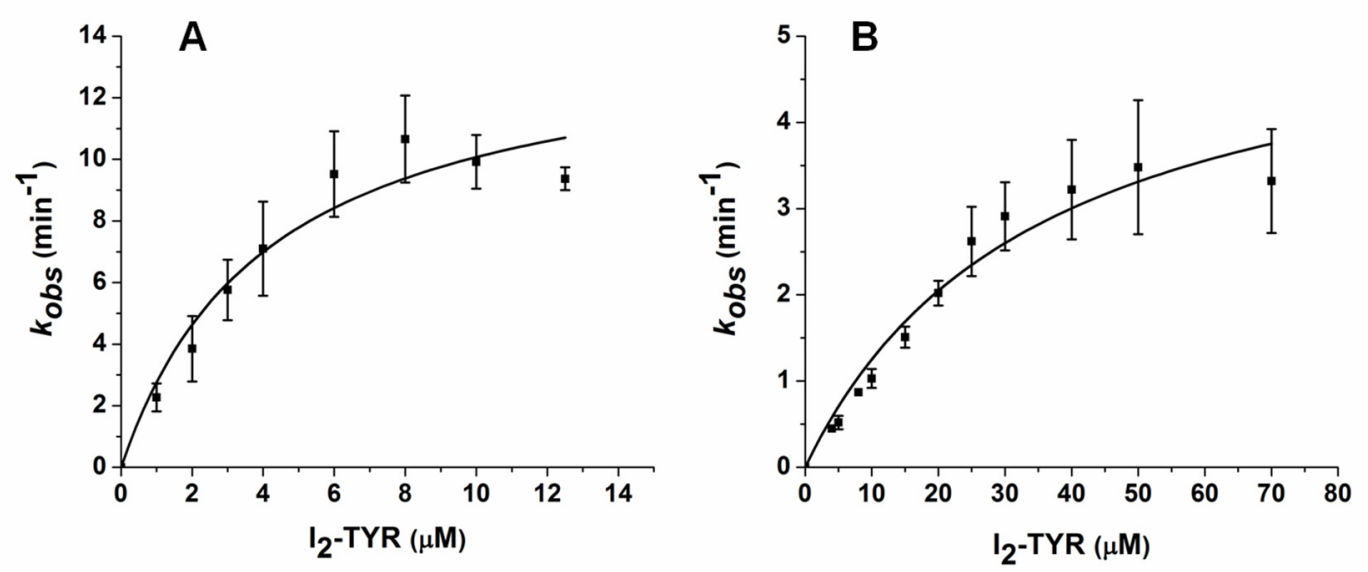

Figure S2. Catalytic deiodination of $I_{2}$-TYR by wt hhIYD and its T173A mutant. Reductive deiodination promoted by (A) wt hhIYD (50 nM) and (B) its T173A mutant (300 $\mathrm{nM})$ was measured by release of $\left[{ }^{125} \mathrm{I}\right]$-iodide from $\left[{ }^{125} \mathrm{I}\right]-\mathrm{I}_{2}$-Tyr as described previously. ${ }^{9,}{ }^{10}$ Assays solutions contained 100 $\mathrm{mM}$ MES pH 6, $500 \mathrm{mM} \mathrm{NaCl}, 10 \%$ glycerol, the indicated concentration of $\mathrm{I}_{2}$-Tyr and components of the standard assay ( $450 \mu \mathrm{M}$ methimazole, $27 \mu \mathrm{M}$ FMN, $666 \mathrm{mM} \mathrm{KCl})$. Reaction at $25^{\circ} \mathrm{C}$ was initiated by addition of sodium dithionite ( $1 \%$ final concentration) as the reductant. Measurements were performed in triplicate and the kinetic parameters were derived from a fit of the average $k_{o b s}$ at each concentration of $\mathrm{I}_{2}$-Tyr to the Michaelis-Menton equation using Origin 7.0. The error bars represent the standard deviation of the three repetitions.

A

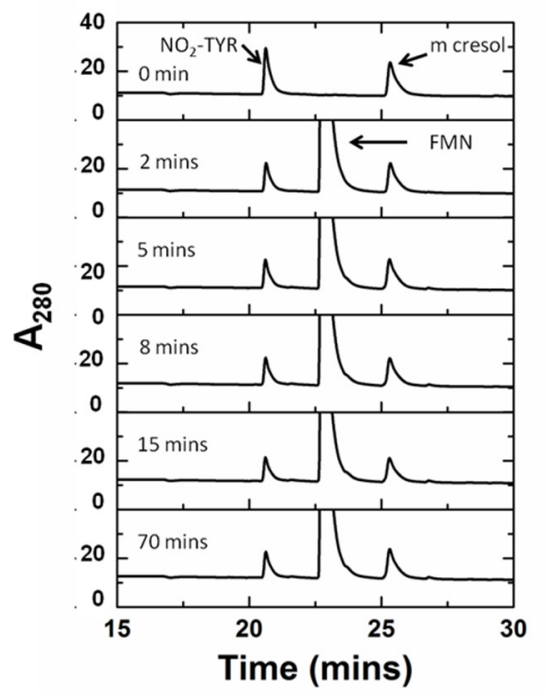

B

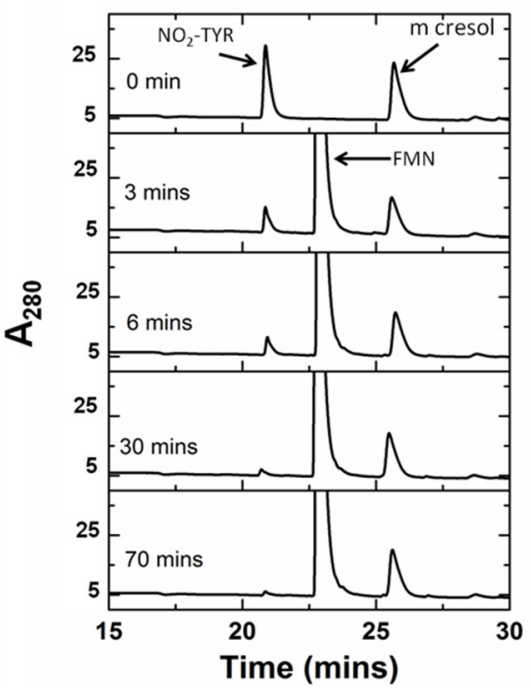

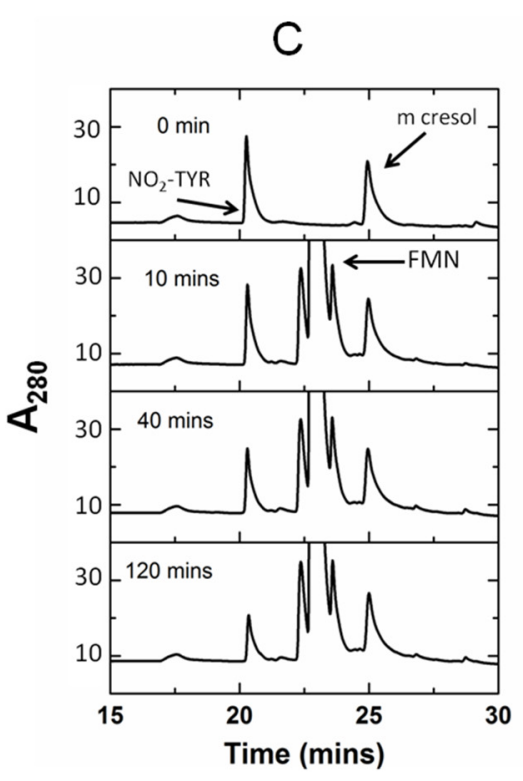

Figure S3. Consumption of $\mathrm{O}_{2} \mathrm{~N}-\mathrm{Tyr}$ by free and enzyme-bound $\mathrm{FMN}_{\mathrm{hq}}$. Anaerobic solutions of (A) $18 \mu \mathrm{M}$ wt hhIYD containing FMN $\mathrm{F}_{\mathrm{hq}}$, (B) $18 \mu \mathrm{M}$ T173A hhIYD containing FMN $\mathrm{N}_{\mathrm{hq}}$, and (C) $18 \mu \mathrm{M}$ free $\mathrm{FMN}_{\mathrm{hq}}$ were prepared as described in the experimental section (p. S2). Reaction was initiated by addition of $8 \mu \mathrm{M} \mathrm{O}_{2} \mathrm{~N}$-Tyr. Aliquots $(150 \mu \mathrm{L})$ of the reactions were removed at the indicated times, quenched with trifluoroacetic acid (TFA) to a final concentration of $1.5 \%$ and centrifuged to remove the protein precipitate. The supernatant was separated by reverse-phase $\mathrm{C}-18$ HPLC using aqueous TFA $(0.1 \%)$ (Buffer A) for $10 \mathrm{~min}$, a gradient of $0-45 \%$ acetonitrile with $0.1 \%$ TFA (buffer B) for the following $20 \mathrm{~min}$ and finally $45-100 \%$ buffer B for the last $4 \mathrm{~min}(1 \mathrm{~mL} / \mathrm{min})$. Under these conditions, $\mathrm{O}_{2} \mathrm{~N}-\mathrm{Ty}, \mathrm{FMN}$, and $m$-cresol elute at 21, 23, 25 min, respectively. Concentration of $\mathrm{O}_{2} \mathrm{~N}-$ Tyr was calculated by integrating its signal relative to that of the added standard $m$-cresol. 
Figure S4. Mass spectroscopy of the dansylation reaction product. Mass spectroscopic characterization (UPLC-ESI) of the dansylated derivative of $\mathrm{H}_{2} \mathrm{~N}-\mathrm{Tyr}$ formed by reaction between (A) wt hhIYD containing $\mathrm{FMN}_{\text {hq }}$ and $\mathrm{O}_{2} \mathrm{~N}-\mathrm{Tyr},(\mathrm{B})$ the T173A mutant containing $\mathrm{FMN}_{\mathrm{hq}}$ and $\mathrm{NO}_{2}-\mathrm{TYR}$ and $(\mathrm{C})$ a $\mathrm{H}_{2} \mathrm{~N}-$ Tyr standard. Materials were separated by HPLC using the following gradient of solvent A (25 mM ammonium formate $\mathrm{pH} 5.7$ and 14\% acetonitrile) and $\mathrm{B}$ (acetonitrile): $0 \% \mathrm{~B}$ for $0-5$ min; 0-8\% B from 5-10 min; $8 \%$ B from 10-25 min; $8-45 \%$ B from 25-55 min; 45-58 \% B from $55-60 \mathrm{~min}(1 \mathrm{~mL} / \mathrm{min})$. The product eluting at 54 min (see Figure 4) was subjected to UPLCESI analysis. The $\mathrm{m} / \mathrm{z}$ values of 430.14 and 663.19 correspond to the theoretical values for the mono and didansylated product of $\mathrm{H}_{2} \mathrm{~N}-\mathrm{Tyr}$.

Figure S5. Stoichiometry of $\mathrm{O}_{2} \mathrm{~N}$-Tyr reduction by FMN $_{\text {hq }}$ bound to T173A hhIYD. A solution of the T173A mutant of hhIYD $(18 \mu \mathrm{M})$ was prepared and degassed as described previously. The protein-bound $\mathrm{FMN}_{\text {ox }}$ was reduced by a stoichiometric amount of dithionite as described in the standard assay (p. S2). $\mathrm{O}_{2} \mathrm{~N}-\mathrm{Tyr}(6 \mu \mathrm{M})$ was then added and allowed to react under ambient conditions until the $\mathrm{A}_{450}$ signal stabilized for $5 \mathrm{~min}$. An aliquot of this mixture $(150 \mu \mathrm{L})$ was quenched with TFA to a final concentration of $1.5 \%$ and the protein precipitate removed by centrifugation. The supernatant was then analyzed by HPLC as described in Figure $\mathrm{S} 3$. Additional $\mathrm{O}_{2} \mathrm{~N}-\mathrm{Ty}$ was then added to increase its total concentration to $8 \mu \mathrm{M}$. Again, after the A450 remained stable for $5 \mathrm{~min}$, another $150 \mu \mathrm{L}$ aliquot was removed for HPLC analysis. This procedure was repeated one more time after the final concentration of $\mathrm{O}_{2} \mathrm{~N}-\mathrm{Tyr}$ was increased to $10 \mu \mathrm{M}$.
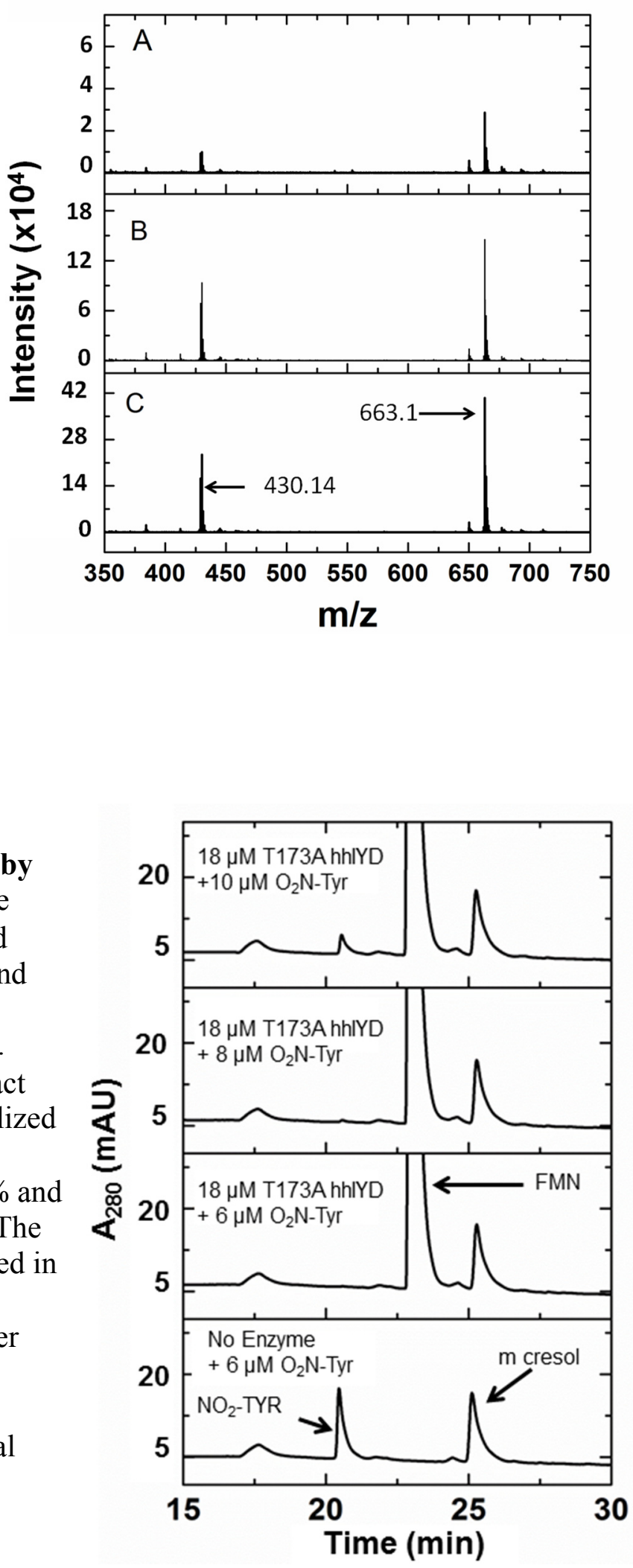
Figure S6. HPLC analysis of reaction between sodium bisulfite and nitrotyrosine and phenylhydroxylamine.

Individual solutions of $500 \mu \mathrm{M}$ $\mathrm{NaHSO}_{3}$ in $100 \mathrm{mM}$ MES pH 6, $500 \mathrm{mM} \mathrm{NaCl}$ and $10 \%$ glycerol were degassed with a stream of argon for $45 \mathrm{~min}$ before alternative addition of (A) $25 \mu \mathrm{M} \quad \mathrm{O}_{2} \mathrm{~N}$-Tyr with a standard of $m$-cresol $(50 \mu \mathrm{M})$ and (B) $8 \mu \mathrm{M}$ phenylhydroxylamine (PhNHOH). The mixtures were incubated at under ambient conditions in the absence of air for $1 \mathrm{hr}$ and then separated by reverse-phase HPLC. Separation for (A) used the solvent gradient described in Figure S3. Separation for (B) used a gradient of acetonitrile in buffer A (25 mM ammonium formate $\mathrm{pH} 6.4)$ according to $0 \%$ acetonitrile form $0-10 \mathrm{~min}, 0-10 \%$ acetonitrile from $10-17 \mathrm{~min}$, a constant $10 \%$ acetonitrile from 17-22 min and a wash of 10-100\% acetonitrile from $22-26 \mathrm{~min}(1 \mathrm{~mL} / \mathrm{min})$.

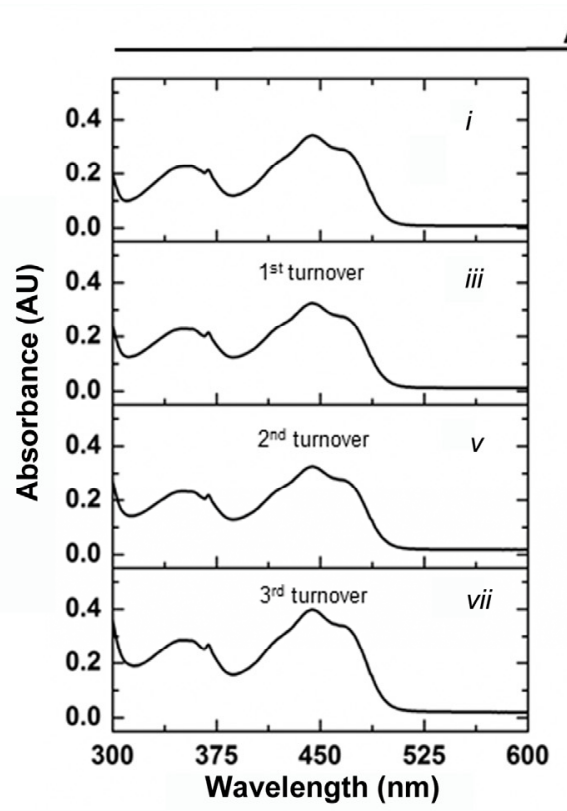

A

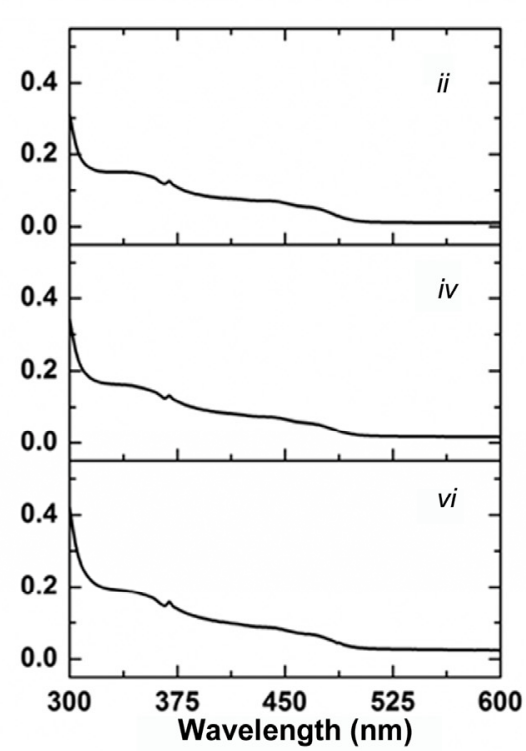

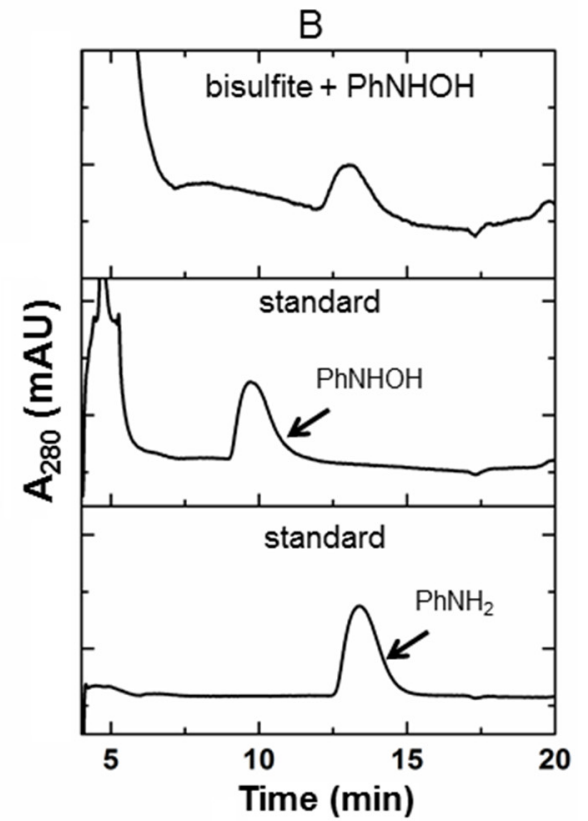

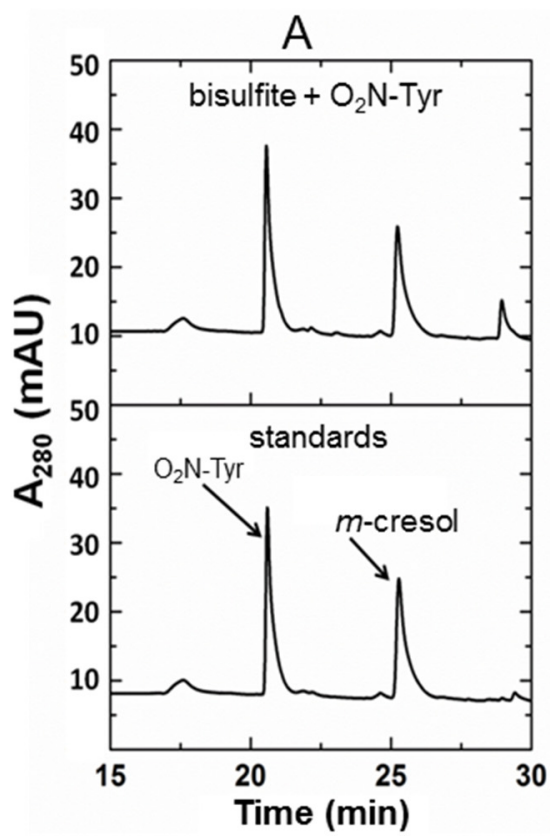

B

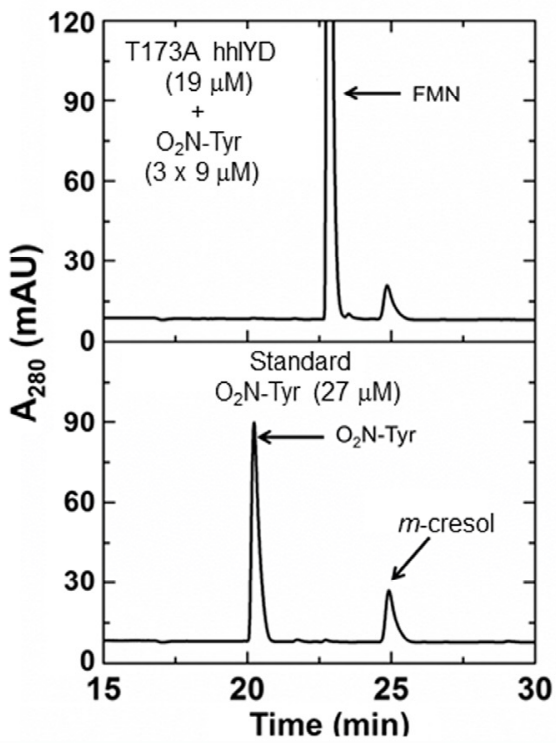

Figure S7. Multiple turnover of T173A hhIYD during reduction of $\mathrm{O}_{2} \mathrm{~N}$-Tyr. A solution of the T173A mutant $(19 \mu \mathrm{M})$ in $100 \mathrm{mM}$ MES pH 6, $500 \mathrm{mM} \mathrm{NaCl}, 10 \%$ glycerol and $50 \mu \mathrm{M} m$-cresol was degassed with argon and its UV-vis spectrum recorded (Ai). The enzyme was then reduced with minimal addition of dithionite as described in the Methods section and its UV-vis spectrum recorded again (Aii). This was reoxidized by the addition of $9 \mu \mathrm{M} \mathrm{O}_{2} \mathrm{~N}-\mathrm{Tyr}$ as indicated by the resulting UV-vis spectrum (Aiii). This cycle was repeated two more times for a total addition of $27 \mu \mathrm{M} \mathrm{O}_{2} \mathrm{~N}-\mathrm{Tyr}$. (B) The final mixture was quenched with TFA and analyzed by HPLC as described in Figure S3. This was compared to a standard sample of $27 \mu \mathrm{M} \mathrm{O}{ }_{2} \mathrm{~N}$-Tyr and $50 \mu \mathrm{M} m$-cresol. 


\section{References}

1. $\quad$ Phatarphekar, A.; Buss, J. M.; Rokita, S. E., Mol. BioSyst. 2014, 10, 86-92.

2. Gasteirger, E.; Hoogland, C.; Gattiker, A.; Duvaud, S.; Wilkins, M. R.; Appel, R. D.; Bairoch, A., Protein Identification and Analysis Tools on the ExPASY Server. In The Proteomics Protocols Handbook, Walker, J. M., Ed. Humana Press: Totowa, 2005; pp Ch. 52, p. 571-607.

3. McTamney, P. M.; Rokita, S. E., J. Am. Chem. Soc. 2009, 131, 14212-14213.

4. Koziol, J., Methods Enzymol. 1971, 18 part C, 253-285.

5. $\quad$ Tapuhi, Y.; Schmidt, D. E.; Lindner, W.; Karger, B. L., Anal. Biochem. 1981, 115, 123-9.

6. $\quad$ Negro, A.; Garbisa, S.; Gotte, L.; Spina, M., Anal. Biochem. 1987, 160, 39-46.

7. Hu, J.; Chuenchor, W.; Rokita, S. E., J. Biol. Chem. 2015, 290, 590-600.

8. $\quad$ Warner, J. R.; Copley, S. D., Biochemistry 2007, 46, 13211-13222.

9. $\quad$ Rosenberg, I. N.; Goswami, A., Methods Enzymol. 1984, 107, 488-500.

10. Friedman, J. E.; Watson, J. A., Jr.; Lam, D. W.-H.; Rokita, S. E., J. Biol. Chem. 2006, 281, 2812-2819. 